\title{
EFEITO DO HIPOCLORITO DE SÓDIO, FOTOPERÍODO E TEMPERATURA NO ESTABELECIMENTO IN VITRO DE JABUTICABEIRA
}

\section{EFFECT OF SODIUM HYPOCHLORITE, PHOTOPERIOD AND TEMPERATURE ON IN VITRO ESTABLISHMENT OF "JABUTICABA" TREE}

\author{
Luciano PICOLOTTO ${ }^{*}$ * \\ Márcia Wulff $\mathrm{SCHUCH}{ }^{2}$ \\ Joseane Almeida de SOUZA ${ }^{3}$ \\ Luciane Couto SILVA ${ }^{4}$ \\ Juçara FERRI ${ }^{5}$ \\ José Carlos FACHINELLO ${ }^{6}$
}

\begin{abstract}
RESUMO
O presente trabalho teve por objetivo testar a influência de diferentes concentrações de hipoclorito de sódio, fotoperíodo e temperatura na desinfestação e germinação in vitro de sementes de jabuticabeira. O meio de cultivo utilizado foi o MS. Sementes de jabuticaba, que foram mantidas sob duas condições durante 8 dias a temperatura de $5^{\circ} \mathrm{C}$ e a temperatura ambiente foram desinfestadas nas concentrações de 2,5\% e 5,0\% de hipoclorito de sódio sendo após inoculadas em tubo de ensaio contendo $10 \mathrm{~mL}$ de meio. Após a inoculação, $50 \%$ das sementes foram colocadas no escuro sob temperatura de $25 \pm 2{ }^{\circ} \mathrm{C}$ e $50 \%$ transferidas para sala de crescimento com 16 horas de fotoperíodo, radiação de $27 \mu \mathrm{mol} \mathrm{m}^{-2} \mathrm{~s}^{-1} \mathrm{e}$ a mesma temperatura. Aos 7, 14, 21, 28 e 35 dias de cultivo avaliou-se a porcentagem de contaminação fúngica e bacteriana, além da porcentagem de oxidação. Aos 42 dias de cultivo também avaliou-se a porcentagem de germinação. O percentual de germinação mais elevado ocorreu nas sementes submetidas a $5^{\circ} \mathrm{C}$. A utilização de hipoclorito de sódio a $5 \%$ se mostrou eficiente na desinfestação diminuindo a contaminação fúngica. A menor contaminação bacteriana ocorreu nas sementes mantidas em temperatura ambiente em presença de luz. Conclui-se que a germinação de sementes de jabuticabeira somente foi influenciada pela temperatura, não tendo influência do fotoperíodo. A contaminação fungica é inversamente proporcional a concentração de desinfestante utilizada, sem haver influência na contaminação bacteriana.
\end{abstract}

Palavras-chave: Propagação; contaminação; desinfestação; Myrciaria spp.

\begin{abstract}
The aim of this work was to test the influence of different concentrations of sodium hypochlorite, photoperiod and temperature on the disinfestations and in vitro germination of "jabuticaba" seeds. The used culture medium was MS. The "jabuticaba" seeds kept under two conditions for 8 days at $5^{\circ} \mathrm{C}$ and room temperature were disinfested in $2,5 \%$ and $5,0 \%$ sodium hypochlorite solution and then inoculated in test tubs containing $10 \mathrm{~mL}$ of medium. After inoculation $50 \%$ of the seeds were placed in the darkness under $25 \pm 2{ }^{\circ} \mathrm{C}$ and $50 \%$ were transferred to the growth room at the same temperature, with 16-hours photoperiod and radiation of $27 \mu \mathrm{mol} \mathrm{m}^{-2} \mathrm{~s}^{-1}$. The assessments of bacteria and fungi contamination percentage and oxidation percentage were done during the $7^{\text {th }}, 14^{\text {th }}, 21^{\text {th }}, 28^{\text {th }}$ and $35^{\text {th }}$ day of the cultivation. Also on the $42^{\text {th }}$ cultivation day it was evaluated the germination percentage. The seeds submitted to $5^{\circ} \mathrm{C}$ had the highest germination percentage. The 5,0\% sodium hypochlorite solution showed efficient in the disinfestations decreasing fungi contamination. The lowest bacteria contamination occurred in the seeds kept at room temperature in the light presence. It was concluded that the "jabuticaba" seeds germination was influenced by the temperature, and the photoperiod did not appear to have an effect. The fungi contamination is inversely proportional to the used disinfector concentration showing no influence in the bacterial contamination.

Key-words: Propagation; contamination; disinfestations; Myrciaria spp.

${ }^{1}$ Engenheiro Agrônomo, doutorando do Programa de Pós Graduação em Agronomia, área de concentração em Fruticultura de Clima Temperado. FAEM/UFPEL. Caixa postal 354, 96010-900, Pelotas, RS. E-mail: picolotto@gmail.com *Autor para correspondência;

${ }^{2}$ Engenheira Agrônoma, Dra., Professora do Departamento de Fitotecnia, FAEM/UFPel. E-mail: marciaws@ufpel.tche.br;

${ }^{3}$ Engenheira Agrônoma, M.Sc., Doutoranda do Programa de Pós Graduação em Agronomia, área de concentração em Fruticultura de Clima Temperado. FAEM/UFPEL.E-mail: joseas@ufpel.tche.br;

${ }^{4}$ Engenheira Agrônoma, Mestranda do Programa de Pós Graduação em Agronomia, área de concentração em Fruticultura de Clima Temperado. FAEM/UFPEL. E-mail: lucianecouto@yahoo.com.br

${ }^{5}$ Graduanda em Agronomia, Bolsista PIBIC/CNPQ-UFPel. E-mail: juferri@pop.com.br;

${ }^{6}$ Engenheiro Agrônomo, Dr., Professor do Departamento de Fitotecnia, FAEM/UFPel. E-mail: jfachi@ufpel.tche.br; Apoio MCT-CNPq, FAPERGS.
\end{abstract}




\section{INTRODUÇÃO}

A jabuticabeira (Myrciaria spp.) é uma fruteira originada do Centro Sul do Brasil podendo ser encontrada desde o estado do Pará até o Rio Grande do Sul. A jabuticabeira apresenta porte médio a grande, com $6 \mathrm{~m}$ a $8 \mathrm{~m}$ de altura, podendo alcançar até $12 \mathrm{~m}$, tendo como tendência típica o hábito de frutificação nos ramos com ruptura da casca (LORENZI et al., 2006).

O método de propagação da jabuticabeira é por via seminífera, sendo este o método mais utilizado pelos produtores (MANICA, 2000), porém esse método faz com que a entrada em produção das plantas se torne lenta devido ao grande período juvenil que esse tipo de propagação acarreta (ANDRADE e MARTINS, 2003). No entanto métodos alternativos, como a propagação in vitro, surgem como uma possibilidade real para obtenção de mudas mais vigorosas e com melhor padrão fitossanitário (PAIVA et al., 2002).

O cultivo in vitro, constitui uma estratégia importante para solucionar problemas não apenas no âmbito da propagação, mas também do melhoramento genético clássico e da biotecnologia de plantas, especialmente das lenhosas perenes (ERIG e SCHUCH, 2003). Neste contexto, o sistema de propagação in vitro tem grande influência nas medidas de controle e prevenção da contaminação, sendo assim importante a determinação de um protocolo de estabelecimento. Segundo SILVA et al. (2005) as substâncias mais utilizadas no processo de desinfestação são os compostos à base de cloro e o etanol. Em fitopatologia, compostos a base de cloro são utilizados na eliminação de contaminantes superficiais de material vegetal e de ambientes (COUTINHO et al., 2000).

Para algumas espécies de frutíferas de clima temperado com dificuldade de germinação não basta somente eliminar as contaminações microbianas das sementes, é necessário ainda submetê-las a baixas temperaturas. As sementes necessitam de um período de estratificação sob frio, que varia de espécie para espécie e também entre cultivares. Dessa forma, possibilita-se que ocorra o processo da quebra ou superação da dormência fisiológica, o que as torna metabolicamente ativas e aptas para iniciar a germinação (BARBOSA et al., 1987).

O experimento teve como objetivo testar concentrações de hipoclorito de sódio, fotoperíodo e temperatura na desinfestação e germinação in vitro de sementes de jabuticabeira.

\section{MATERIAL E MÉTODOS}

O trabalho foi realizado no Laboratório de Micropropagação de Plantas Frutíferas, Departamento de Fitotecnia da Faculdade de Agronomia Eliseu Maciel, da Universidade Federal de Pelotas, RS, no período de junho a julho de 2004. O material vegetal constituiu-se de sementes retiradas de frutos maduros colhidos na zona rural do município de Pelotas.
Os tratamentos constituíram-se de diferentes concentrações de hipoclorito de sódio (2,5\% e $5 \%)$, ausência de luz e presença de luz (16 horas) e temperatura $\left(5^{\circ} \mathrm{C}\right.$ e $\left.25^{\circ} \mathrm{C}\right)$, totalizando oito tratamentos.

Foi feita a eliminação da polpa, a lavagem e a secagem das sementes. A polpa foi retirada manualmente, a lavagem das sementes foi somente com água e a secagem feita em temperatura ambiente $\left( \pm 25{ }^{\circ} \mathrm{C}\right)$. Após o preparo das sementes, as mesmas foram divididas em dois lotes, sendo metade das mesmas mantidas a temperatura de $5{ }^{\circ} \mathrm{C}$ e a outra metade mantida em temperatura ambiente, por um período de oito dias.

A desinfestação das sementes foi realizada em condições assépticas em câmara de fluxo laminar, onde as sementes foram colocadas em álcool $70 \%$ por 30 segundos, seguido pela imersão em uma solução de hipoclorito de sódio (2,5 e 5\%), adicionada de 2 gotas de Tween 20, por um período de 20 minutos, e após, lavadas por três vezes em água destilada autoclavada.

Após a assepsia de todo material, o mesmo foi transferido para tubos de ensaio, contendo meio de cultivo com volume de $10 \mathrm{~mL}$ em cada tubo. $\mathrm{O}$ meio de cultivo utilizado foi o MS (MURASHIGE e SKOOG, 1962). O pH do meio foi ajustado para 5,8 antes da inclusão do ágar, na concentração de $6 \mathrm{~g} \mathrm{~L}^{-1}$ e, em seguida, autoclavado a $121^{\circ} \mathrm{C}$ e $1,5 \mathrm{~atm}$, por 20 minutos.

A etapa seguinte foi colocar todas as sementes em sala de crescimento, sendo parte das mesmas submetidas à ausência total de luminosidade e as demais a um fotoperíodo de 16 horas de luz a 27 $\mathrm{mmol} \mathrm{m}{ }^{-2} \mathrm{~s}^{-1}$, ambas a temperatura de $25 \pm 2{ }^{\circ} \mathrm{C}$.

Aos 7, 14, 21, 28, 35 e 42 dias foram avaliadas as porcentagens de oxidação, de contaminação fúngica e bacteriana, os frascos com contaminação foram anotados e eliminados. Aos 42 dias de cultivo, avaliou-se a porcentagem de germinação, a qual foi determinada pelo desenvolvimento dos primórdios foliares e radículas.

$O$ delineamento experimental utilizado foi inteiramente casualizado, com esquema fatorial $2 \times 2 \times 2$, sendo quatro repetições por tratamento. Cada repetição constituiu-se de cinco tubos com um explante (semente). Os dados foram submetidos à análise de variância e as médias dos tratamentos comparadas estatisticamente pelo teste de Duncan. Os dados em porcentagem foram transformados em arco seno da raiz quadrada de $x / 100$.

\section{RESULTADOS E DISCUSSÃO}

Para porcentagem de germinação, o fator temperatura foi altamente significativo $(\alpha=0,01)$, com a baixa temperatura apresentando maior germinação que a temperatura ambiente, com germinação média de $4,4 \%$ quando as sementes foram submetidas a $5{ }^{\circ} \mathrm{C}$ e $0 \%$ na temperatura de $25^{\circ} \mathrm{C}$. Por outro lado a germinação em função 
do fotoperíodo e temperatura não diferiu estatisticamente (Tabela 1).

$$
\text { Resultados semelhantes foram }
$$
encontrados por ANDRADE e MARTINS (2003), os quais observaram que há influência da temperatura sobre a germinação, sendo que sob baixas temperaturas verificou-se uma maior porcentagem de germinação para três clones de jabuticabeira, no entanto a porcentagem de germinação encontrada por estes autores foi superior a encontrada no presente trabalho. Neste sentido verifica-se que possivelmente existam outros fatores que influenciam a germinação das sementes de jabuticabeira, sendo que novas investigações serão importantes para determinação de metodologia mais adequada para a germinação desta espécie.

TABELA 1 - Porcentagem de germinação observada em função da variação de temperatura e fotoperíodo em sementes de jabuticabeira aos 42 dias de cultivo in vitro.

\begin{tabular}{lcc}
\hline Temperatura & \multicolumn{2}{c}{ Germinação (\%) } \\
\cline { 2 - 3 } & Ausếncia de luz & Presença de luz (16 horas) \\
\hline $5^{\circ} \mathrm{C}$ & 2,0 aA* & 0,0 aA \\
$25^{\circ} \mathrm{C}$ & 8,0 aA & 0,0 aA \\
\hline
\end{tabular}

* Médias seguidas de mesma letra, minúscula na coluna e maiúscula na linha, não diferem entre si pelo Teste de Duncan, ao nível de $5 \%$ de probabilidade.

Uma possível causa para a baixa porcentagem de germinação nas sementes de jabuticabeira poderá estar relacionada a impermeabilidade do tegumento da semente. MOORE et al. (1974), ao estudarem a espécie Rubus fruticosus, observaram que as sementes não germinaram em até 12 meses de observações, ao contrário do embrião nu, que germinou $90 \%$ em 15 dias.

$\mathrm{Na}$ contaminação bacteriana, foram observadas diferenças altamente significativas entre as temperaturas. Altas taxas de contaminação foram visualizadas na baixa temperatura, com níveis de $86,73 \%$ no material submetido a $5^{\circ} \mathrm{C}$ e $52,52 \%$, nas sementes expostas a $25^{\circ} \mathrm{C}$ (Figura 1). Conforme DANTAS et al. (2002), grande parte da população bacteriana fitopatogênica encontra-se em locais protegidos, como irregularidades das superfícies vegetais, pelos e mucilagens, podendo escapar a ação dos produtos desinfestantes.

Relatos da presença de microrganismos endofíticos em tecidos vegetais têm sido verificados em relação a um grande número de espécies de plantas (RAPS e VIDAL, 1998 apud PEREIRA et al., 2003). Embora seus efeitos sejam pouco conhecidos, sob condições in vitro, a presença destes microrganismos constitui-se numa das mais importantes causas de perda de material vegetal. FORTES et al. (2004), estudando a sobrevivência de acessos de amendoim (Arachis hipogaea) na germinação in vitro, verificaram que 27 acessos (cerca de $93 \%$ dos acessos estudados) apresentaram algum nível de contaminação bacteriana, sendo que na maioria do material estudado a contaminação variou de $10 \%$ a $90 \%$. De acordo com estes autores, esse tipo de contaminação é o que mais ocorre em cultivos in vitro.

Ainda na contaminação bacteriana, nas sementes que não receberam luz verificou-se, aos 7 e 14 dias de cultivo, maior contaminação bacteriana chegando a $53,02 \%$ e $68,90 \%$ para as respectivas datas e nas sementes que receberam 16 horas de luz observou-se um uma menor contaminação $(28,80 \%$ e $43,35 \%$, respectivamente).

Para a variável oxidação no fator temperatura, as diferenças foram altamente significativas $(=0,05)$. Nos dias avaliados, os níveis mais baixos de oxidação, foram nas sementes submetidas à temperatura ambiente (Tabela 2). Conforme estudos, as plantas superiores em condições adequadas, produzem várias substâncias denominadas metabólicos secundários, os quais, em sua maioria, são de natureza fenólica (PAIVA et al., 2000), especialmente as pertencentes a família Myrtaceae (FACHINELLO et al., 1995).

Com relação à contaminação fúngica verificouse que a concentração de $5 \%$ de hipoclorito de sódio foi mais eficiente que a $2,5 \%$ (Figura 2). O mecanismo de ação do cloro não é bem conhecido, embora algumas hipóteses sugiram que há uma combinação com proteínas da membrana celular dos microrganismos, assim formando compostos tóxicos e levando à inibição das enzimas essenciais (DONINI et al., 2005). 

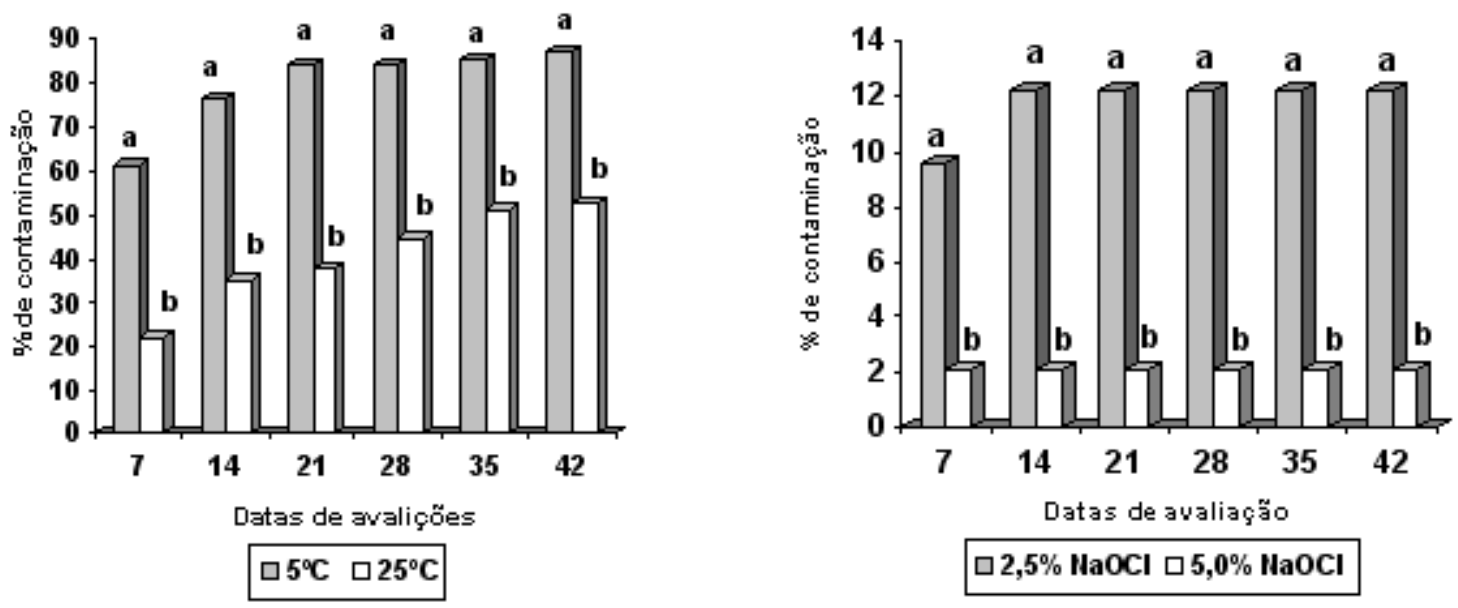

FIGURA 1 - Porcentagem de contaminação bacteriana em função da temperatura de 7 a 42 dias de cultivo in vitro.

TABELA 2 - Porcentagem de oxidação observada em função da variação de temperatura em sementes de jabuticabeira aos $7,14,21$, 28,35 e 42 dias de cultivo in vitro.

\begin{tabular}{lccccc}
\hline \multicolumn{5}{c}{ \% de oxidaçä́o nos dias de cultivo } \\
Temperatura & 7 & 14 & 21 & 35 & 42 \\
\hline $5^{\circ} \mathrm{C}$ & $85,60 \mathrm{a}$ & $99,66 \mathrm{a}$ & $99,92 \mathrm{a}$ & $99,92 \mathrm{a}$ & $99,92 \mathrm{a}$ \\
$25^{\circ} \mathrm{C}$ & $71,65 \mathrm{a}$ & $71,66 \mathrm{~b}$ & $87,83 \mathrm{~b}$ & $87,83 \mathrm{~b}$ & $87,83 \mathrm{~b}$ \\
\hline
\end{tabular}

Médias seguidas de letras distintas na coluna diferem entre si, ao nível de significância de 0,05.

Resultados semelhantes foram observados por COUTINHO et al. (2000), estudando os efeitos do hipoclorito de sódio na germinação de conídios de alguns fungos transmitidos por semente. Os autores observaram que os valores de germinação de conídios nos tratamentos que foram utilizadas as concentrações de 1,0;2,0 e 5,0\% foram inferiores aos da testemunha e ao do tratamento em que foi empregada a concentração de $0,5 \%$ do produto.

Para a variação de temperatura, verificou-se a estabilização da contaminação a partir dos 14 dias de cultivo, com $7,42 \%$ na temperatura de $25^{\circ} \mathrm{C}$ e $13,17 \%$ em sementes submetidas a temperatura de $5^{\circ} \mathrm{C}$ estando estes resultados de acordo com FORTES et al. (2004). Segundo estes autores no cultivo in vitro este tipo de agente contaminante, apesar de presente e causar danos, não é tão importante como as bactérias, ficando nítido que a contaminação, tanto por fungo quanto por bactéria, se expressam nos primeiros dias de cultivo (FORTES et al., 2004).

\section{CONCLUSÕES}

A baixa temperatura $\left(5^{\circ} \mathrm{C}\right)$ propicia a redução da formação de compostos fenólicos e estimula a germinação com a quebra de dormência da jabuticabeira.

O hipoclorito de sódio a $5 \%$ tem boa eficiência como desinfestante na contaminação fúngica, proporcionando redução nas taxas de contaminação.

O fotoperíodo não influencia a germinação das sementes de jabuticabeira.

\section{REFERÊNCIAS}

1. ANDRADE, R.A.; MARTINS, A.B.G. Influence of the temperature in germination of seeds of jabuticaba tree. Revista Brasileira Fruticultura, Jaboticabal, v. 25, n. 1, p. 197-198, 2003.

2. BARBOSA, W.; CAMPO DALL'ORTO, F.A.; OJIMA, M.; MARTINS, F.P.; RIGITANO, O. Emergência de plântulas do pêssego porta-enxerto Okinawa; influência de períodos de estratificação e de ácido giberélico. Bragantia, Campinas, v. 46, n. 2, p. 435-441, 1987.

3. COUTINHO, W.M.; PEREIRA, L.A.A. SILVA, O.F.; PENA, R.C.M.; MAGALHÃES, F.H.L. Efeitos de hipoclorito de sódio na germinação de conídios de alguns fungos transmitidos por semente. Revista Fitopatologia Brasileira, Brasília, v. 25, n. 3, p. 552555,2000

4. DANTAS, S.A.F.; OLIVEIRA, S.M.A.; CÂMARA, T.R. Contaminação microbiana no cultivo in vitro de plantas. Revisão anual de patologia de plantas, Passo Fundo, v. 10, p. 391-407, 2002.

5. DONINI, L.P.; FERREIRA-MOURA, I.; GUISSO, A.P.; SOUZA, J.A. DE; VIÉGAS, J. Preparo de lâminas foliares de aráceas ornamentais: desinfestação com diferentes concentrações de hipoclorito de sódio. Arquivo do Instituto de Biologia, São Paulo, v. 72 , n. 4, p. 517-522, 2005 
PICOLOTTO, L. et al. Efeito do hipoclorito de sódio...

6. ERIG, A.C.; SCHUCH, M.W. Estabelecimento in vitro de plantas de marmeleiro (Cydonia oblonga mill.) cultivares MC, Adams e Portugal. Revista Científica Rural, Bagé, v. 8, n. 2, p. 107-115, 2003.

7. FACHINELLO, J.C.; HOFFMANN, A.; NACHTIGAL, J.C.; KERSTEN, E.; FORTES, G.R. de L. Propagação de plantas frutíferas de clima temperado. Pelotas: Editora e Gráfica Universitária da UFPEL, 1995. 178 p.

8. FORTES, G. de L; FREITAS, F. de O.; FORTES, M.A.; VALLS, J.F.M. Sobrevivência de acessos de amendoim (Arachis hipogaea) através de germinação in vitro. Brasília: Embrapa Recursos Genéticos e Biotecnologia, 2004. $15 \mathrm{p}$.

9. LORENZI, H.; BACHER, L.; LACERDA, M.; SARTORI, S. Frutas brasileiras e exóticas cultivadas. São Paulo: Instituto Plantarum de Estudos da Flora, 2006. 640 p.

10. MANICA, I. Frutas nativas, silvestres e exóticas: 1 - Técnicas de produção e mercado. Abiu, amora-preta, araçá, bacuri, biriba, carambola, cereja do rio grande, jabuticaba. Porto Alegre: Cinco Continentes, 2000. $327 \mathrm{p}$.

11. MOORE, J.N; BROWN, G.R.; LUNDERGAN, C. Effect of duration of acid scarification on endocarp thickness and seedling emergence of blackberries. HortScience, Alexandria, v. 9, n. 3, p. 204-205, 1974.

12. MURASHIGE, T.; SKOOG, F. A revised medium for rapid growth and biossay with tabacco tissue cultures. Physiologia Plantarum, Kobenhavn, v. 15, p.473-497, 1962.

13. PAIVA, P.D.O.; CARDOSO, M. das G.; PASQUAL, M.; PAIVA, R. Identificação de compostos liberados no meio de cultura pelo processo de oxidação em cultivo in vitro de estrelícia (Strelitzia reginae ait.). Ciência e Agrotecnologia, Lavras, v. 24 (edição especial), p. 50-55, 2000.

14. PAIVA, R.; GOMES. G.A.C.; SANTANA, J.R.F.; PAIVA, P.D.O.; DOMBROSKI, J.L.D.; SANTOS, B.R. Espécies frutíferas com potencial econômico: avanços no processo de propagação. Informe Agropecuário, Belo Horizonte, v. 23, n. 216, p. 78-84, 2002.

15. PEREIRA, J.E.S.; MATTOS, M.L.T.; FORTES, G.R.D.L. Identificação e controle com antibióticos de bactérias endofíticas contaminantes em explantes de batata micropropagados. Pesquisa Agropecuária Brasileira, Brasília, v. 38, n. 7, p. 827-834, 2003.

16. SILVA, P.C.; DIAS, J.M.M.; NEVES, J.C.L.; SALOMÃO, L.C.S.; COUCEIRO, M.A.; ROCHA, M.A. Protocolo para desinfestação de sementes de tangerineira Cleópatra (Citrus reshni Hort. ex Tan.). Disponível em <http://www.ufpel.tche.br/sbfruti/ anais_xvii_cbf/fitotecnia/317.htm/> Acesso em mar. 2005.

Recebido em 25/10/2005 Aceito em 23/03/2007 